\title{
Evaluation of municipal e-government readiness using structural equation modelling technique
}

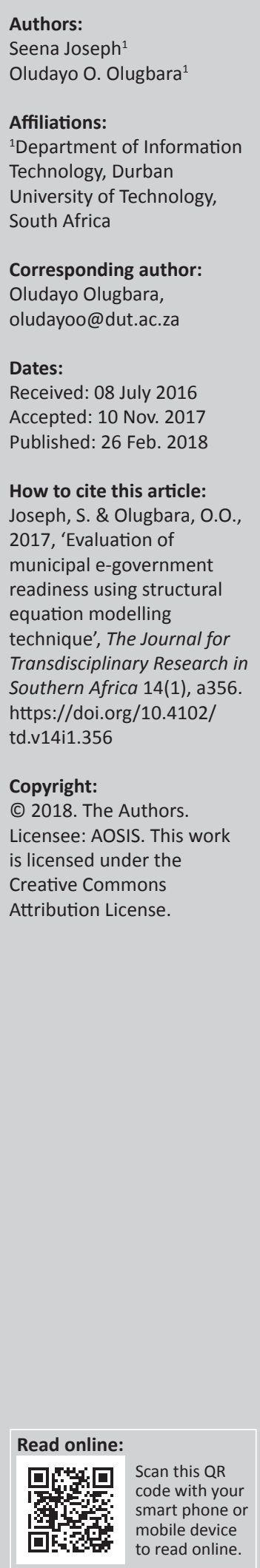

The evaluation of municipal e-government readiness can provide a useful barometer to understand the critical needs of citizens. In addition, it can help to improve effectiveness of government services and provide a technology industry access to relevant information to create efficient e-services. This study develops and tests a framework to evaluate municipal e-government readiness based on building blocks of supporting e-services readiness, individual citizen readiness, municipal government readiness, technological infrastructure readiness and supporting industries readiness. The process of evaluating municipal e-government readiness utilises data obtained through a survey of 219 respondents from four municipalities in the Eastern Cape Province of South Africa. The partial least square structural equation modelling technique was used for data analysis. The study results show that the investigated building blocks are significant determinants of municipal e-government readiness with an overall $81 \%$ goodness-of-fit performance. The results provide foundational information for policymakers and practitioners who are interested in propagating e-government readiness. Factors that determine municipal e-government readiness could provide new insights on future studies about e-municipality service improvement.

\section{Introduction}

The assignment of reinventing government has been a primary theme since the 1990s, with governments all over the world trying to improve the system of public services delivery. The accelerated growth of information communication technology (ICT) systems is revolutionising the way government services are delivered nowadays. The government services and processes can be better managed by using a variety of ICT platforms, applications and services (Gupta, Shakya \& Marasini 2015:155). Government agencies and industries can be empowered by the use of ICT to provide efficient and transparent services to citizens (Angeleski et al. 2014:1). This permits the government to implement new ways of delivering services to citizens, industries and government agencies. In other words, the information society has redefined the way governments operate to change the mechanisms of service delivery (Máchová \& Lněnička 2015:384). The phenomenon of electronic government, which is henceforth called e-government, is derived from the desire for efficient service delivery. e-Government is predicated on leveraging the potentials of ICT to deliver improved government services to citizens, businesses, suppliers and public organisations (Sayin \& Okursoy 2013:37). Local governments are authorised to deliver services to the citizens with the power to raise revenue and receive transfers from provincial and national governments (Twum-Darko 2014:513). However, because of the intrinsic complexity of governance, whether at the municipal level or at the national level, e-government initiatives are often collaborative in nature. This collaborative effort brings together diverse units of governments, private sectors, non-governmental organisations, civic societies and citizens as the key stakeholders of e-government (Potnis 2010:41).

Since the late 1990s, all levels of government around the world have been developing e-government systems. Public service delivery occurs at all levels of government, but citizen-oriented services are mainly supplied by municipalities that are essential entities in the local government. Municipalities are the closest form of governmental structure through which the citizens feel the direct impacts of government (Mawela, Ochara \& Twinomurinzi 2017:149). The majority of e-government services is progressively executed at the municipal level rather than at the national level. The introduction of electronic systems in the administrative and organisational aspects of municipal work is imperative for the effective and efficient delivery of public services (Sayin \& Okursoy 2013:39). The knowledge about local context, the existing environment, opportunities and challenges for a given municipality can develop a realistic e-government (Dzhusupova et al. 2010). A municipality is an important entity in the local government sphere that must carry out critical functions of efficient service delivery to all citizens in its area of jurisdiction. However, 
owing to the lack of qualified personnel and technical and organisational capacities, many municipalities have not made a full commitment to develop a comprehensive strategic e-government plan to achieve an advanced level of e-government (Mawela et al. 2017; Sarrayrih \& Sriram 2015; Twum-Darko 2014). Municipalities will need to move towards a higher level of e-government development in order to enhance the effectiveness of e-government practices. This obviously requires an initial evaluation of the available resources to adequately address e-government readiness.

The e-government readiness framework reported in this article has been tested on data elicited from four district municipalities in South Africa. A district municipality (Category C municipality) comprises several local municipalities (Category B municipalities) and has the authority to execute certain operations of the local government. A local municipality serves as the third and the most local sphere of local government that includes rural areas and one or more towns or small cities. In larger urban areas where there are no district municipalities or local municipalities, a metropolitan municipality (Category A municipality) is responsible for all municipal affairs. The municipalities would benefit from e-government to improve quality of service delivery as well as increase transparency and accessibility to public services.

The overarching objective of this study is to integrate factors that have been identified in the literature to contribute to e-government readiness under a single framework for evaluating e-government readiness at the municipal level. Different casual factors have been identified in the literature for evaluating e-government readiness of a country (Ahmed \& Hussein 2006; Alghamdi, Goodwin \& Rampersad 2011; Azab, Kamel \& Dafoulas 2009; Khalil 2011; Yuan, Xi \& Xiaoyi 2012; Zheng \& Jiang 2011). However, the diverse research streams are isolated and factors identified have not been coherently integrated into an overall scheme for evaluating municipal e-government readiness.

\section{Evaluation of e-government readiness}

e-Government readiness is an important indicator of the quality of ICT infrastructure. It is the ability of citizens to use ICT and organisations to benefit from the modern technologies in a country (Máchová \& Lněnička 2015:383). The evaluation of e-government readiness has attracted the attention of many researchers in recent times (Ahmed \& Hussein 2006; Alghamdi et al. 2011; Azab, Kamel \& Dafoulas 2009; Khalil 2011; Yuan et al. 2012; Zheng and Jiang 2011). Ahmed and Hussein (2006) proposed a conceptual framework with six significant factors for the success of e-government initiatives that consequently increase the e-government readiness level of a country, which are government organisational readiness, governance and leadership readiness, customer readiness, competency readiness, technology readiness and legal readiness. The study concludes that the implementation of the framework ensures that e-government initiatives would not face any major legal quagmire. Moreover, it guarantees the success of e-government initiatives and increases the e-government readiness level of a country. Azab et al. (2009) proposed an e-government readiness framework that adopts a four-phase model to categorise e-government into four internal factors, namely strategy, process, technology and people. The findings of the research were based on a case study strategy with qualitative and quantitative data collection. Results indeed indicate that all proposed internal factors directly affect e-government readiness.

The conceptual e-government readiness framework presented by Alghamdi et al. (2011) contributes an organisational perspective to the measurement of ICT readiness for e-government. The proposed framework contains seven dimensions of ICT readiness of government organisations, including e-government strategies, user access, e-government programmes, ICT architectures, business processes and information systems, ICT infrastructures and human resources. The study is an essential conceptual step to discovering significant factors in an organisational perspective. Khalil (2011) developed a readiness model that explores cultural values and practices to evaluate e-government readiness. These include power distance, future orientation, assertiveness, gender differentiation, performance orientation, human orientation, uncertainty avoidance, in-group collectivism and institutional collectivism. Gross domestic product (GDP) is added as a control variable. The study utilised the reported survey from UNDESA (2008) for the findings and showed that cultural values have a significant effect on predicting e-government readiness than cultural practices and that GDP is an important determinant of e-government readiness.

The readiness framework developed by Zheng and Jiang (2011) is based on a bottom-up approach to identify factors for evaluating e-government readiness. The framework includes two major building blocks, namely external environment e-readiness indicators and internal government e-readiness indicators. External environment readiness comprises social ICT infrastructure as well as social and human environment. Internal government readiness is composed of managerial framework, leadership, investment, workforce capability, internal IT infrastructure, information safety as well as the legal and regulatory environment. The hybrid method of qualitative with quantitative techniques was used to analyse the empirical data. The study found that the indicators developed from a location-specific context may not be generalised to different conditions. Yuan et al. (2012) developed a Government Portal Performance Architecture (GPPA) based on the theory of web quality evaluation and contemporary public administration principles to evaluate e-government readiness in China. The measurement criteria focused on a government portal website in terms of its content, function and construction. The results of the empirical study revealed that the effectiveness of e-government readiness impacts the performance of government portals. 
It could be observed that while recognising the notable contributions of extant studies on e-government readiness evaluation, very little has been written on readiness grades of e-government at the municipal level of government. In addition, it would fill the gap in the literature by providing a general framework for evaluating municipal e-government readiness. Consequently, the authors of this article have investigated five primary building blocks to evaluate e-government initiatives at the municipal level of government. These building blocks represent the basic components to be evaluated before launching the e-government agenda that can guarantee the right implementation in the right direction. Figure 1 shows the five building blocks to be supporting e-services readiness, individual citizen readiness, municipal government readiness, technological infrastructure readiness and supporting industries readiness. The building blocks can comprehensively be evaluated in terms of 13 evaluation metrics and 96 conceptual measures as described in the section on research methods. In this study, building blocks are evaluation areas that were assembled from the literature to directly measure municipal e-government readiness. The concepts of an evaluation metric and a conceptual measure were borrowed from the literature (Scholtz \& Consolvo 2004). Accordingly, a conceptual measure is an observable value of a building block and an evaluation metric associates meaning to that value by applying human judgement, which in this study is done through a survey method.

The explanation of the building blocks of the municipal e-government readiness framework (Figure 1) with the associated evaluation metrics follows in the subsequent sections.

\section{Supporting e-services readiness}

Supporting e-services are all the interactive services that are delivered on the internet using the advanced

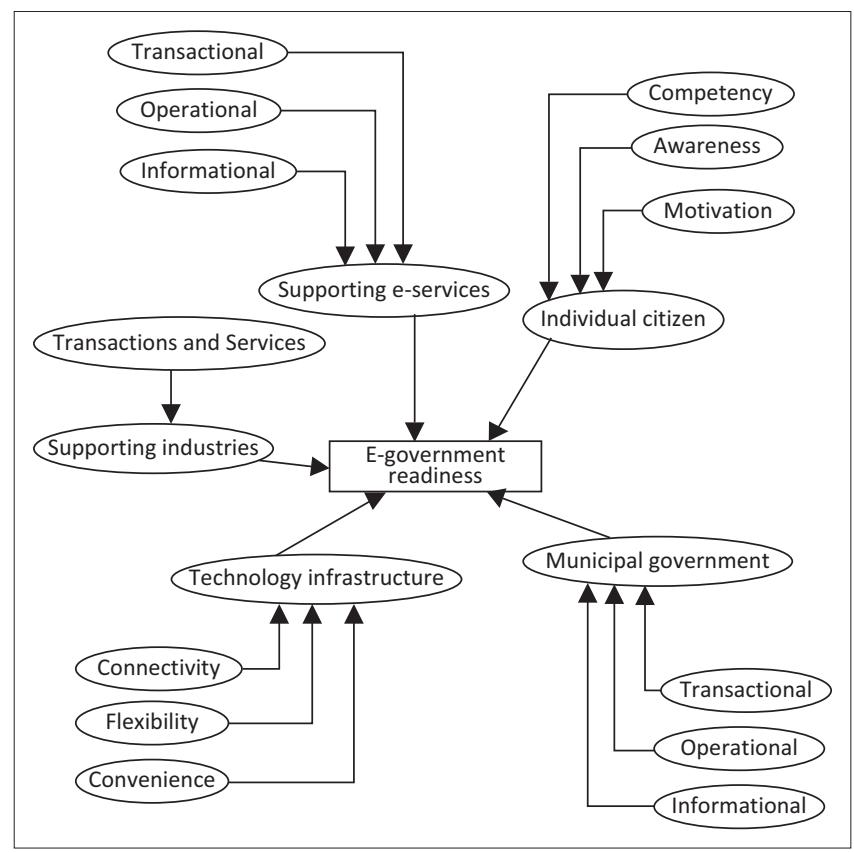

FIGURE 1: Municipal e-government readiness framework. telecommunication technologies, information technologies, cloud technologies and multimedia technologies (Joseph 2014; Koh, Prybutok \& Zhang 2008). The importance of this building block in the context of e-government has been noted by some researchers (Angeleski et al. 2014; Koh et al. 2008; Shin-Ping Liu 2012; Yuan et al. 2012; Yunis \& Sun 2009). In this study, the supporting e-services are evaluated in terms of informational use, transactional use and operational use metrics as defined below.

- Informational use - organisational dissemination of information to educate, entertain, influence or reach citizens.

- Transactional use - a coordinated sequence of users and system activities to provide services and transfer values.

- Operational use - a new mechanism for conducting business operations by integrating information systems, human intellect and other resources in a synergistic network.

Three evaluation metrics based on informational use, transactional use and operational use have been applied in this study to evaluate supporting e-services readiness in order to transform a municipality into a provider of fully integrated e-government services. Next is the discussion of individual citizen readiness, which is considered an important building block of the municipal e-government readiness framework.

\section{Individual citizen readiness}

Various studies have emphasised individual citizen readiness as one of the factors that has significant impacts on e-government readiness (Ahmed \& Hussein 2006; Alghamdi et al. 2011; Alghamdi, Goodwin \& Rampersad 2014; Angeleski et al. 2014; Azab et al. 2009; Rahman 2007; Yunis \& Sun 2009; Waheduzzaman \& Miah 2015; Zheng and Jiang 2011). The individual citizen readiness involves the evaluation of citizens who are the primary consumers of e-government services in terms of their competency on e-government processes, policies and relationships; awareness to participate in e-government services; and motivation for the willingness to adopt and promote e-government (Joseph 2014; Sarrayrih \& Sriram 2015). The willingness of citizens to make effective use of e-services has been considered as one of the most dominating factors to successfully embrace e-government (Rehman, Esichaikul \& Kamal 2012:259; Sarrayrih \& Sriram 2015:234). In this study, competence, awareness and motivation are considered as important factors driving willingness to effectively use e-services and are used to evaluate individual citizen readiness as explained below.

- Competency - ensures that citizen competencies in support of e-government initiatives are defined, acquired, developed and sustained for e-government design, delivery and operations.

- Awareness - the extent to which the society understands e-government initiatives, e-government privacy and security management. 
- Motivation - the support provided for citizens to effectively participate in the e-government implementation activities.

The measurement of individual citizen readiness along three evaluation metrics is proposed in this study in order to understand the extent to which citizens support e-government initiatives. The next discussion is on the evaluation of municipal readiness, which is considered important to the municipal e-government readiness framework of this study.

\section{Municipal government readiness}

The municipal government readiness is the preparedness of government to integrate and coordinate data for the smooth interaction among the various e-services and e-applications (Krauss 2009). The importance of government readiness as a critical aspect of e-government has already been stressed in many studies (Ahmed \& Hussein 2006; Alghamdi et al. 2011, 2014; Azab et al. 2009; Rahman 2007; Koh et al. 2008; ShinPing Liu 2012; Zheng and Jiang 2011). In this study, the readiness of municipal government is evaluated in terms of evaluation metrics that are related to strategy, system and data support as discussed below.

- Strategy - the planning and alignment of internet activities with the business objectives for the preparedness for a large-scale systemic change.

- System - the coordination and integration of different internet applications across different functions and services.

- Data support - the organisation of data in a unified and standardised form that best enables robust and diverse third-party use.

This study has proposed three evaluation metrics based on strategy, system and data support through which e-government readiness at the municipal level should be addressed. The next important building block of the municipal e-government readiness framework is the technology infrastructure readiness.

\section{Technology infrastructure readiness}

Technology infrastructure readiness involves all the necessary technology resources such as hardware, software, communication platform, network infrastructure, network architecture, internet penetration and technology services to provide a foundation for e-government applications and services across municipalities (Joseph 2014). Experts have appreciated the inclusion of technology infrastructure as one of the dimensions that has significant importance in e-government readiness (Ahmed \& Hussein 2006; Alghamdi et al. 2011, 2014; Azab et al. 2009; Baeuo, Rahim \& Alaraibi 2017; Gupta et al. 2015; Shin-Ping Liu 2012; Yunis \& Sun 2009; Zheng and Jiang 2011). The technology infrastructure readiness is evaluated in this study in terms of three evaluation metrics of connectivity, flexibility and convenience as discussed below.
- Connectivity - the ability of any technology component to attach to any other components inside and outside the organisational environment.

- Flexibility - the ability to easily and readily support a wide variety of hardware, software, communication technologies, data and core applications in an e-government environment.

- Convenience - the citizen insight of the time and endeavour that are essential to use an e-government.

Technology infrastructure readiness has an important role in the effective implementation of e-government services (Singh \& Chauhan 2012:34). However, equally important for evaluating municipal e-government readiness is the building block of supporting industries readiness.

\section{Supporting industries readiness}

The supporting industries readiness refers to the evaluation of the presence, development, service level and cost structure of supports that are given by institutions such as the telecommunications, financial and ICT industry whose activities might affect the e-government services in a municipality (Alghamdi et al. 2011). The importance of supporting industries readiness has been highlighted by several researchers (Ahmed \& Hussein 2006; Alghamdi et al. 2011, 2014; Alghamdi, Goodwin \& Rampersad 2016; Azab et al. 2009; Rahman 2007). In this study, the supporting industries readiness is evaluated in terms of services and transactions that involve the following:

- The availability of reliable internet technology infrastructure, reliable logistics services and universal communication standards that are sufficient to support the e-government services and transactions in a municipality.

The validation of the municipal e-government readiness framework through the structural equation modelling (SEM) technique (Hair, Ringle \& Sarstedt 2011) is discussed in the next section.

\section{Research methods}

As mentioned earlier, the objective of this study is to integrate factors that have been identified in the literature to contribute to e-government readiness under a single framework to evaluate e-government readiness at the municipal level. To this end, the required data were collected through a survey on a sample representing government employees from four municipalities - Amathole, Buffalo City, King Sabata Dalindyebo (KSD) and OR Tambo (ORT) of the Eastern Cape Province in South Africa. The first part of the survey sought information on the demographic profile of respondents. The second part focused on the conceptual measures of the five building blocks of supporting e-services readiness, individual citizen readiness, municipal government readiness, technology infrastructure readiness and supporting industries readiness. Each conceptual measure in the second part reflects the scoring of an evaluation metric for a corresponding building block of the municipal e-government readiness framework. 
Consequently, all conceptual measures were associated with a seven-point semantic differential scale ranging from 1 to 7 with anchors at each end of the scale. Different response anchors (completely not provided 1, 2, 3, 4, 5, 6, 7 completely provided; very low 1, 2, 3, 4, 5, 6, 7 very high; very low awareness 1, 2, 3, 4, 5, 6, 7 very high awareness; lowly motivated $1,2,3,4,5,6$, 7 highly motivated; poorly connected 1, 2, 3, 4, 5, 6, 7 well connected; highly inconvenient 1 , 2, 3, 4, 5, 6, 7 highly convenient; highly inflexible 1, 2, 3, 4, 5, 6, 7 highly flexible; strongly disagree 1, 2, 3, 4, 5, 6, 7 strongly agree) were used based on the type of conceptual measures provided. As discussed earlier, conceptual measures in the context of this study are questions asked in the survey.

\section{Research sampling characteristics}

The analysis of demographic data reflects that many of the respondents were in the age group of 26-35 (44.7\%) compared with other age groups: $16-25(2.3 \%), 36-45(26.9 \%), 46-55$ $(21.0 \%)$ and $>55(5.0 \%)$ as shown in Table 1 . The number of male respondents $(56.6 \%)$ was higher than the number of female respondents $(43.4 \%)$. The majority of respondents $(40.6 \%)$ reside in a township which is an underdeveloped segregated urban residential area. Of the respondents, 32.9\% were from rural areas and $26.5 \%$ were from urban areas.

TABLE 1: Profile of respondents $(N=219)$.

\begin{tabular}{|c|c|c|c|}
\hline Characteristics & Category & Frequency & $\%$ \\
\hline \multirow[t]{5}{*}{ Age of respondent } & $16-25$ & 5 & 2.30 \\
\hline & $26-35$ & 98 & 44.70 \\
\hline & $36-45$ & 59 & 26.90 \\
\hline & $46-55$ & 46 & 21.00 \\
\hline & $>55$ & 11 & 5.00 \\
\hline \multirow[t]{2}{*}{ Gender of respondent } & Female & 95 & 43.40 \\
\hline & Male & 124 & 56.60 \\
\hline \multirow{4}{*}{$\begin{array}{l}\text { Experience with } \\
\text { computers }\end{array}$} & Never & 3 & 1.40 \\
\hline & $<1$ year & 21 & 9.60 \\
\hline & $<2$ year & 34 & 15.50 \\
\hline & $>2$ year & 161 & 73.50 \\
\hline \multirow{4}{*}{$\begin{array}{l}\text { Experience with } \\
\text { e-government }\end{array}$} & Never & 73 & 33.30 \\
\hline & $<1$ year & 57 & 26.00 \\
\hline & $<2$ year & 38 & 17.40 \\
\hline & $>2$ year & 51 & 23.30 \\
\hline \multirow{5}{*}{$\begin{array}{l}\text { Internet access using } \\
\text { computer }\end{array}$} & Never & 13 & 5.90 \\
\hline & Yearly & 5 & 2.30 \\
\hline & Monthly & 11 & 5.00 \\
\hline & Weekly & 44 & 20.10 \\
\hline & Daily & 146 & 66.70 \\
\hline \multirow{5}{*}{$\begin{array}{l}\text { Internet access using } \\
\text { mobile phones }\end{array}$} & Never & 24 & 11.00 \\
\hline & Yearly & 4 & 1.80 \\
\hline & Monthly & 27 & 12.30 \\
\hline & Weekly & 66 & 30.10 \\
\hline & Daily & 98 & 44.70 \\
\hline \multirow[t]{2}{*}{ Owning computers } & No & 84 & 38.40 \\
\hline & Yes & 135 & 61.60 \\
\hline \multirow[t]{3}{*}{ Residence location } & Rural & 72 & 32.90 \\
\hline & Township & 89 & 40.60 \\
\hline & Urban & 58 & 26.50 \\
\hline \multirow[t]{4}{*}{ Municipality } & O R Tambo & 26 & 11.90 \\
\hline & King Sabata Dalindyebo & 41 & 18.70 \\
\hline & Buffalo City & 126 & 57.50 \\
\hline & Amathole & 26 & 11.90 \\
\hline
\end{tabular}

A large number of respondents owned computers (61.6\%), while $38.4 \%$ of respondents did not own computers. The majority of respondents had more than two years of experience using computers (73.5\%). About 15.5\% of respondents had more than one year of experience using computers, $9.6 \%$ of respondents had less than one year experience of using computers and only $1.4 \%$ of respondents stated that they never used computers. Many of the respondents agreed that they had experience using e-government $(66.7 \%)$, while $33.3 \%$ of them had no experience using e-government. Among the experienced respondents using e-government, $23.3 \%$ had more than two years of experience, $17.4 \%$ had more than one year of experience and $26.0 \%$ had less than one year of experience.

Most of the respondents had access to the internet, whether through mobile phones or computers. About $66.7 \%$ of the respondents stated that they accessed the internet using a computer daily, $20.1 \%$ of respondents accessed weekly, 5\% accessed monthly and 2.3\% accessed yearly. Only 5.9\% of respondents had never accessed the internet using a computer. About $44.7 \%$ of respondents stated that they accessed the internet using mobile phones daily, 30.1\% accessed weekly, 12.3\% accessed monthly and 1.8\% accessed yearly. Only $11 \%$ of respondents had never accessed the internet using mobile phones.

\section{Confirmatory factor analysis}

The SEM technique was used to test the municipal e-government readiness framework discussed in the section on evaluation of e-government readiness by utilising the responses of 219 government employees. Structural equation modelling is generally a multivariate approach that allows the simultaneous examination of the causal relationships that exist among the exogenous (independent) latent factors and endogenous (dependent) latent factors within a model (Alavifar, Karimimalayer \& Anuar 2012:326). The SEM approach can be classified into covariance-based SEM, which is implemented by the AMOS software (https://www.ibm. $\mathrm{com} / \mathrm{ms}$-en/marketplace/structural-equation-modelingsem) and component-based SEM, which is generally called the partial least square (PLS) that is implemented by the SmartPLS software (https://www.pls-sem.net/news-1/ new-smartpls-3-software-for-pls-sem/). The covariancebased SEM requires the sample data under investigation to be of normal distribution, which may not always be the case. In sharp contrast, the PLS makes no underlying assumption about data distribution, so it can effectively work with unobservable factors and it takes measurement errors into consideration (Aibinu \& Al-Lawati 2010:719). This study has applied the PLS technique because of its ability to handle heterogeneous data with a small sample size and because of its popularity, superiority and generality when compared with the covariance-based SEM (Hair et al. 2011:144).

The municipal e-government readiness framework was tested in terms of the statistical metrics of reliability and validity using the SmartPLS version 2.0 software (https:/ / 
TABLE 2: Scale properties with the following legend - Awareness (1), Citizen (2), Competency (3), Connectivity (4), Convenience (5), Data (6), Flexibility(7), Municipal government (8), Industry( 9), Information (10), Motivation (11), Operation (12), Municipal e-government (13), Service (14), Strategy (15), System (16), Technology (17), Transaction (18), Transaction and services (19), Internal consistency (20), Composite reliability (21), Average variance extracted (22).

\begin{tabular}{|c|c|c|c|c|c|c|c|c|c|c|c|c|c|c|c|c|c|c|c|}
\hline & 1 & 2 & 3 & 4 & 5 & 6 & 7 & 8 & 9 & 10 & 11 & 12 & 13 & 14 & 15 & 16 & 17 & 18 & 19 \\
\hline 1. & 1.00 & & & & & & & & & & & & & & & & & & \\
\hline 2. & 0.68 & 1.00 & & & & & & & & & & & & & & & & & \\
\hline 3. & 0.77 & 0.89 & 1.00 & & & & & & & & & & & & & & & & \\
\hline 4. & 0.68 & 0.61 & 0.68 & 1.00 & & & & & & & & & & & & & & & \\
\hline 5. & 0.71 & 0.63 & 0.69 & 0.81 & 1.00 & & & & & & & & & & & & & & \\
\hline 6. & 0.69 & 0.49 & 0.51 & 0.66 & 0.70 & 1.00 & & & & & & & & & & & & & \\
\hline 7. & 0.66 & 0.59 & 0.62 & 0.70 & 0.85 & 0.69 & 1.00 & & & & & & & & & & & & \\
\hline 8. & 0.70 & 0.54 & 0.60 & 0.70 & 0.74 & 0.69 & 0.71 & 1.00 & & & & & & & & & & & \\
\hline 9. & 0.59 & 0.58 & 0.59 & 0.64 & 0.67 & 0.68 & 0.61 & 0.68 & 1.00 & & & & & & & & & & \\
\hline 10. & 0.51 & 0.35 & 0.38 & 0.47 & 0.49 & 0.58 & 0.48 & 0.45 & 0.45 & 1.00 & & & & & & & & & \\
\hline 11. & 0.63 & 0.53 & 0.61 & 0.70 & 0.72 & 0.70 & 0.70 & 0.58 & 0.67 & 0.51 & 1.00 & & & & & & & & \\
\hline 12. & 0.63 & 0.48 & 0.52 & 0.57 & 0.56 & 0.61 & 0.55 & 0.55 & 0.51 & 0.74 & 0.58 & 1.00 & & & & & & & \\
\hline 13. & 0.67 & 0.62 & 0.67 & 0.72 & 0.73 & 0.63 & 0.67 & 0.74 & 0.71 & 0.48 & 0.62 & 0.55 & 1.00 & & & & & & \\
\hline 14. & 0.45 & 0.30 & 0.35 & 0.45 & 0.50 & 0.44 & 0.49 & 0.47 & 0.41 & 0.64 & 0.52 & 0.52 & 0.46 & 1.00 & & & & & \\
\hline 16. & 0.70 & 0.52 & 0.55 & 0.69 & 0.74 & 0.85 & 0.72 & 0.80 & 0.68 & 0.55 & 0.62 & 0.64 & 0.72 & 0.49 & 0.84 & 1.00 & & & \\
\hline 17. & 0.67 & 0.60 & 0.70 & 0.84 & 0.77 & 0.59 & 0.68 & 0.69 & 0.62 & 0.34 & 0.65 & 0.47 & 0.67 & 0.46 & 0.67 & 0.61 & 1.00 & & \\
\hline 18. & 0.61 & 0.51 & 0.57 & 0.54 & 0.59 & 0.56 & 0.54 & 0.55 & 0.53 & 0.65 & 0.58 & 0.67 & 0.59 & 0.59 & 0.57 & 0.57 & 0.52 & 1.00 & \\
\hline 19. & 0.63 & 0.47 & 0.49 & 0.61 & 0.65 & 0.79 & 0.62 & 0.61 & 0.83 & 0.58 & 0.66 & 0.58 & 0.67 & 0.43 & 0.71 & 0.71 & 0.55 & 0.53 & 1.00 \\
\hline 20. & 0.96 & 1.00 & 0.96 & 0.96 & 0.93 & 0.92 & 0.95 & 0.95 & 0.91 & 0.91 & 0.94 & 0.93 & 0.95 & 1.00 & 0.95 & 0.95 & 1.00 & 0.91 & 0.92 \\
\hline 21. & 0.97 & 1.00 & 0.97 & 0.97 & 0.96 & 0.94 & 0.97 & 0.98 & 0.96 & 0.92 & 0.95 & 0.94 & 0.96 & 1.00 & 0.96 & 0.96 & 1.00 & 0.93 & 0.95 \\
\hline 22. & 0.77 & 1.00 & 0.85 & 0.93 & 0.88 & 0.76 & 0.91 & 0.96 & 0.92 & 0.51 & 0.79 & 0.50 & 0.84 & 1.00 & 0.77 & 0.82 & 1.00 & 0.65 & 0.87 \\
\hline
\end{tabular}

softadvice.informer.com/Download_Smartpls_Version_2.0.html). The confirmatory factor analysis (CFA) of the SmartPLS software was used to establish whether the widely accepted criteria for reliability and validity were met. Reliability is the extent to which item-level errors are consistent within a single factor, and it was tested by the estimate of internal consistency and composite reliability. The internal consistency was measured using the Cronbach's alpha statistic, which estimates how consistent an individual's responses are to items within a scale and is one of the most widely-used methods for estimating the reliability of an instrument (Tavakol \& Dennick 2011:53). The results showed that all alpha coefficients exceeded the 0.80 benchmark as shown in Table 2, indicating a high level of internal consistency. The composite reliability offers a more retrospective approach to check for internal consistency of a factor itself, including stability and equivalence of the factor and it should be greater than the benchmark of 0.7 to be considered adequate (Aibinu \& Al-Lawati 2010:720). It is perceptible that composite reliabilities of all factors exceeded the required minimum of 0.70 , with the lowest value being 0.92 for informational use of supporting e-services as shown in Table 2. This result demonstrates the adequacy of the municipal e-government readiness framework of this study.

The validity of a framework tells whether a measuring instrument measures what it was supposed to measure. The tests of discriminate validity and convergent validity are used to examine the extent to which measures of latent factors shared their variances and how they are different from others. Discriminant validity tests whether measurements that are not supposed to be related are actually unrelated. The average variance extracted was used to test for discriminant validity, which should be above 0.5 to be acceptable. This constraint is satisfied for this study as shown in Table 2 (Aibinu \& Al-Lawati 2010). Convergent validity means that items within a single factor are highly correlated, which is evident by the standardised factor loading that should be above 0.5 (Hair et al. 2011:146). Tables 3-8 show that all items exhibited loadings higher than 0.5 on their respective factors and significant at $p<0.05$, providing evidence of acceptable convergence validity (Aibinu \& AlLawati 2010:720). The descriptive statistics of conceptual measures are also provided to show how respondents respond to each measure as shown in Tables 3-8 using means and standard deviation (SD) statistics.

\section{Discussion of results}

The results of testing the municipal e-government readiness framework show good item reliability and convergent validity. The predictive power $\left(R^{2}\right)$ of the readiness framework was estimated after the determination of reliability and validity. The results showed that supporting e-services readiness, individual citizen readiness, municipal government readiness, technology infrastructure readiness, industry readiness and municipal e-government readiness have $R^{2}$ values of $0.46,0.79,0.77,0.73,0.69$ and 0.68 , respectively. The $R^{2}$ value of 0.68 indicates $68 \%$ of the municipal e-government readiness as a result of all the five building blocks of the framework. This result suggests that the fit of the readiness framework to the empirical data of this study is at an acceptable level for all the five building blocks. This further indicates that the municipal e-government readiness is satisfactory taken into cognisance the complexity of the framework in terms of the 13 evaluation metrics and 96 conceptual measures. The $R^{2}$ values for the standardised building blocks may be decomposed in terms of the regression coefficients and correlations between the municipal 
TABLE 3: Confirmatory factor analysis of supporting e-services.

\begin{tabular}{|c|c|c|c|}
\hline Conceptual measure & Mean & SD & Loading \\
\hline Publishing of municipality information & 2.51 & 1.53 & 1.00 \\
\hline \multicolumn{4}{|l|}{ Informational use } \\
\hline Publishing of geographical information system data & 2.51 & 1.45 & 0.74 \\
\hline Publishing of municipality budget & 2.05 & 1.33 & 0.78 \\
\hline Publishing of employee manual & 1.92 & 1.28 & 0.77 \\
\hline Tour guide of municipality & 2.36 & 1.42 & 0.69 \\
\hline Publishing of minutes of meeting & 1.87 & 1.31 & 0.65 \\
\hline Information from government & 2.86 & 1.74 & 0.71 \\
\hline Video broadcasting of meeting & 1.64 & 1.05 & 0.69 \\
\hline Audio broadcasting of meeting & 1.55 & 1.00 & 0.75 \\
\hline Broadcasting of live traffic cams & 1.53 & 1.05 & 0.71 \\
\hline TV and postal services & 1.70 & 1.33 & 0.67 \\
\hline Political debate & 1.94 & 1.29 & 0.65 \\
\hline \multicolumn{4}{|l|}{ Transactional use } \\
\hline Calls for bids or proposals & 2.40 & 1.53 & 0.82 \\
\hline Bidder application & 2.37 & 1.32 & 0.77 \\
\hline Utility payments & 2.38 & 1.49 & 0.85 \\
\hline Collection of fees & 2.22 & 1.34 & 0.86 \\
\hline Collection of fines & 2.25 & 1.39 & 0.89 \\
\hline Tax collection & 2.51 & 1.70 & 0.71 \\
\hline Payments to service providers & 2.58 & 1.75 & 0.72 \\
\hline \multicolumn{4}{|l|}{ Operational use } \\
\hline Request for services & 2.55 & 1.59 & 0.74 \\
\hline Resident permits application and renewal & 1.69 & 1.18 & 0.57 \\
\hline Licence and right application and renewal & 1.71 & 1.25 & 0.62 \\
\hline Voter registration & 1.58 & 1.19 & 0.59 \\
\hline Request for records & 1.88 & 1.40 & 0.66 \\
\hline Property and/or intellectual property registration & 1.74 & 1.16 & 0.70 \\
\hline Business or organisation registration & 1.73 & 1.30 & 0.66 \\
\hline Change business or deregister business & 1.81 & 1.31 & 0.69 \\
\hline Surveys and polls & 2.48 & 1.38 & 0.64 \\
\hline Forums and discussion & 2.61 & 1.45 & 0.72 \\
\hline Job application & 3.25 & 1.80 & 0.70 \\
\hline Support for e-mail communication & 3.89 & 2.01 & 0.65 \\
\hline Support for online calendar & 2.63 & 1.64 & 0.66 \\
\hline Support for scheduling meeting online & 2.14 & 1.50 & 0.79 \\
\hline Support for online document management & 2.25 & 1.50 & 0.80 \\
\hline Support for video conferencing & 2.10 & 1.32 & 0.74 \\
\hline Emergency management & 2.17 & 1.39 & 0.72 \\
\hline
\end{tabular}

SD, standard deviation.

e-government readiness and the five building blocks. The decomposition allows for the understanding of the contribution of each building block in predicting the municipal e-government readiness and shows that municipal government readiness is the most significant building block. It contributes to $37.62 \%$ of the $R^{2}$ followed by supporting industries readiness $(27.97 \%)$ and individual citizen readiness (17.34\%). Technology infrastructure readiness and supporting e-services readiness contribute $11.90 \%$ and $5.08 \%$ of $R^{2}$, respectively.

The goodness-of-fit (GoF) index proposed by Tenenhaus et al. (2005) is a global evaluation criterion that was used to judge the quality of the municipal e-government readiness framework. Its intention is to account for the performance of the PLS-based framework at both the measurement model and structural model, with a strong focus on the overall prediction power. The GoF index was obtained as the geometric mean of the average communality index and
TABLE 4: Confirmatory factor analysis of individual citizen readiness.

\begin{tabular}{|c|c|c|c|}
\hline Conceptual measure & Mean & SD & Loading \\
\hline $\begin{array}{l}\text { Skills to access information regarding e-government } \\
\text { applications }\end{array}$ & 2.51 & 1.53 & 1.00 \\
\hline \multicolumn{4}{|l|}{ Competency } \\
\hline Knowledge and skills on e-government relationships & 2.73 & 1.55 & 0.91 \\
\hline Knowledge and skills on e-government process & 2.82 & 1.54 & 0.95 \\
\hline Knowledge and skills on e-government policies & 2.84 & 1.60 & 0.93 \\
\hline $\begin{array}{l}\text { Knowledge and skills on e-government industry } \\
\text { structure }\end{array}$ & 2.50 & 1.46 & 0.89 \\
\hline $\begin{array}{l}\text { Skills to govern and coordinate projects related to } \\
\text { e-government }\end{array}$ & 2.73 & 1.56 & 0.92 \\
\hline $\begin{array}{l}\text { Skills to lead people in achieving e-government } \\
\text { adoption success }\end{array}$ & 2.79 & 1.53 & 0.91 \\
\hline \multicolumn{4}{|l|}{ Awareness } \\
\hline $\begin{array}{l}\text { Public advocacy, branding and media adverts on } \\
\text { e-government }\end{array}$ & 2.42 & 1.46 & 0.82 \\
\hline $\begin{array}{l}\text { e-Government training supports at cybercafé, } \\
\text { schools and special centres }\end{array}$ & 2.34 & 1.38 & 0.85 \\
\hline $\begin{array}{l}\text { People understanding about how e-government is } \\
\text { used }\end{array}$ & 2.37 & 1.28 & 0.89 \\
\hline $\begin{array}{l}\text { Requirements placed on people to use } \\
\text { e-government }\end{array}$ & 2.38 & 1.33 & 0.90 \\
\hline Pride in using e-government & 2.46 & 1.41 & 0.88 \\
\hline $\begin{array}{l}\text { e-Government security and privacy awareness } \\
\text { training programmes }\end{array}$ & 2.35 & 1.37 & 0.90 \\
\hline $\begin{array}{l}\text { Commitment of stakeholders to e-government } \\
\text { security and privacy management }\end{array}$ & 2.33 & 1.35 & 0.90 \\
\hline $\begin{array}{l}\text { Relevant regulations and laws of e-government } \\
\text { security and privacy management }\end{array}$ & 2.31 & 1.38 & 0.90 \\
\hline $\begin{array}{l}\text { Government commitment to e-government security } \\
\text { and privacy management }\end{array}$ & 2.26 & 1.36 & 0.86 \\
\hline \multicolumn{4}{|l|}{ Motivation } \\
\hline $\begin{array}{l}\text { Willingness to spend time and effort on } \\
\text { e-government implementation }\end{array}$ & 3.01 & 1.63 & 0.88 \\
\hline $\begin{array}{l}\text { Willingness of non-governmental organisations to } \\
\text { promote e-government }\end{array}$ & 2.84 & 1.46 & 0.90 \\
\hline $\begin{array}{l}\text { Willingness of government to promote } \\
\text { e-government }\end{array}$ & 2.96 & 1.47 & 0.89 \\
\hline $\begin{array}{l}\text { Training on mix aspects of e-government } \\
\text { management and technical areas }\end{array}$ & 2.70 & 1.38 & 0.91 \\
\hline $\begin{array}{l}\text { Initiative to increase willingness of citizen to adopt } \\
\text { e-government }\end{array}$ & 2.79 & 1.49 & 0.88 \\
\hline
\end{tabular}

SD, standard deviation.

average $R^{2}$ value (Hair et al. 2012:426). The results showed that, overall, the $81 \%$ fit of the municipal e-government readiness framework to the empirical data is of higher level and confirm that all the investigated five building blocks and 13 evaluation metrics in this study are good predictors of municipal e-government readiness. The findings of this study generally reveal that the investigated building blocks are significant predictors of municipal e-government readiness. This ensures the importance of giving attention to these building blocks for the successful implementation of e-government at the municipal level.

The effect of supporting e-services readiness ensures the necessity to extend features and online services to e-governmentwebsites. The progression from unsophisticated information services to fully electronic transaction services is key to achieving quality e-services. Citizens are the major factors for the successful implementation of e-government projects; therefore, e-government must be citizen oriented. In general, lack of competence of government employees in using ICT, low level of e-government awareness among the citizens and lack of motivation are the major stumbling blocks for the successful implementation of e-government at 
TABLE 5: Confirmatory factor analysis of municipal government readiness.

\begin{tabular}{|c|c|c|c|}
\hline Conceptual measure & Mean & SD & Loading \\
\hline $\begin{array}{l}\text { The municipality has strategic plans that govern all } \\
\text { internet activities }\end{array}$ & 2.86 & 1.62 & 0.98 \\
\hline $\begin{array}{l}\text { The municipality has clearly stated the objective of } \\
\text { using the internet }\end{array}$ & 2.98 & 1.60 & 0.98 \\
\hline \multicolumn{4}{|l|}{ Strategy } \\
\hline $\begin{array}{l}\text { The internet is an integral part of the municipality } \\
\text { business plan }\end{array}$ & 3.05 & 1.60 & 0.85 \\
\hline $\begin{array}{l}\text { The internet strategies of the municipality are } \\
\text { deliberately aligned with the strategic plans }\end{array}$ & 2.95 & 1.53 & 0.91 \\
\hline $\begin{array}{l}\text { The municipality provides initiatives and guidance } \\
\text { to encourage e-government development process }\end{array}$ & 2.87 & 1.52 & 0.90 \\
\hline $\begin{array}{l}\text { The municipality provides allocation to training, } \\
\text { procurement of ICT infrastructure and maintenance } \\
\text { of investment related to e-government }\end{array}$ & 2.75 & 1.49 & 0.90 \\
\hline $\begin{array}{l}\text { The municipality provides clear and sufficient } \\
\text { e-government policy involving contractual } \\
\text { arrangement and documentation }\end{array}$ & 2.63 & 1.43 & 0.91 \\
\hline $\begin{array}{l}\text { The municipality provides metrics and indicators for } \\
\text { assessing investment and impact of e-government }\end{array}$ & 2.42 & 1.41 & 0.83 \\
\hline $\begin{array}{l}\text { Establishment of well-defined related inter- } \\
\text { municipality e-government strategies plan }\end{array}$ & 2.49 & 1.48 & 0.83 \\
\hline \multicolumn{4}{|l|}{ System } \\
\hline $\begin{array}{l}\text { The municipality carefully coordinates development } \\
\text { of all internet applications }\end{array}$ & 2.77 & 1.59 & 0.89 \\
\hline $\begin{array}{l}\text { The municipality pays close attention to ensuring } \\
\text { compatibility among internet applications }\end{array}$ & 2.77 & 1.38 & 0.93 \\
\hline $\begin{array}{l}\text { The municipality has a centralised function that } \\
\text { oversees the development of all internet applications }\end{array}$ & 2.55 & 1.44 & 0.93 \\
\hline $\begin{array}{l}\text { The internet application at municipality are designed } \\
\text { and developed to work with legacy systems }\end{array}$ & 2.54 & 1.43 & 0.90 \\
\hline $\begin{array}{l}\text { The municipality provides internet infrastructure and } \\
\text { network coverage facilities to bridge digital divide }\end{array}$ & 2.56 & 1.46 & 0.88 \\
\hline \multicolumn{4}{|l|}{ Data } \\
\hline $\begin{array}{l}\text { All internet applications within the municipalities } \\
\text { can share data with other internet applications }\end{array}$ & 2.73 & 1.59 & 0.89 \\
\hline $\begin{array}{l}\text { All internet applications within the municipalities } \\
\text { can share data with non-internet applications }\end{array}$ & 2.65 & 1.47 & 0.92 \\
\hline $\begin{array}{l}\text { All internet applications within the municipalities } \\
\text { share standardised data }\end{array}$ & 2.64 & 1.42 & 0.93 \\
\hline $\begin{array}{l}\text { All government data within the municipalities are } \\
\text { open source }\end{array}$ & 2.42 & 1.40 & 0.79 \\
\hline All government data are provided in local contents & 2.46 & 1.39 & 0.83 \\
\hline
\end{tabular}

ICT, information communication technology; SD, standard deviation.

the municipal level. The high impact of the technology infrastructure readiness emphasises that technology is the main source of change and provides power for enabling the process of implementing e-government initiatives.

e-Government can never exist without an effective application of ICT as a germane tool to advance the internal administrative processes of government. The technological infrastructure with reliable and accessible connectivity needs to be incorporated in municipalities for effective and efficient delivery of e-government services. There is the need for a comprehensive strategic plan and resources in terms of data and system for a successful e-government to take place at the municipal level. Moreover, good investments in the infrastructure development by government and supporting industries should go pari passu with the scheme of service development and transaction improvement at the municipal level to ensure the successful implementation of e-government at the municipal level.

\section{Limitation of the study}

The main shortcoming of this study is that only four municipalities of the Eastern Cape Province of South Africa
TABLE 6: Confirmatory factor analysis of technology infrastructure readiness.

\begin{tabular}{|c|c|c|c|}
\hline Conceptual measure & Mean & SD & Loading \\
\hline $\begin{array}{l}\text { Reliable internet connectivity, broadband speed, cloud } \\
\text { services }\end{array}$ & 3.66 & 2.04 & 1.00 \\
\hline \multicolumn{4}{|l|}{ Connectivity } \\
\hline Appropriate security systems to protect information & 3.39 & 1.86 & 0.96 \\
\hline $\begin{array}{l}\text { Appropriate security systems to protect online } \\
\text { transactions }\end{array}$ & 3.30 & 1.76 & 0.96 \\
\hline $\begin{array}{l}\text { Internet ICT standards that comply with industry } \\
\text { quality standards }\end{array}$ & 3.24 & 1.72 & 0.94 \\
\hline \multicolumn{4}{|l|}{ Convenience } \\
\hline $\begin{array}{l}\text { e-Government applications are convenient and } \\
\text { beneficial to use }\end{array}$ & 3.14 & 1.75 & 0.93 \\
\hline $\begin{array}{l}\text { Response time of e-government applications is } \\
\text { acceptable }\end{array}$ & 3.11 & 1.67 & 0.96 \\
\hline $\begin{array}{l}\text { e-Government applications do not request for much } \\
\text { information }\end{array}$ & 3.16 & 1.69 & 0.93 \\
\hline \multicolumn{4}{|l|}{ Flexibility } \\
\hline e-Government applications are flexible to change & 2.93 & 1.56 & 0.93 \\
\hline $\begin{array}{l}\text { e-government applications response to service } \\
\text { quality issues ensures ease of use }\end{array}$ & 2.86 & 1.47 & 0.97 \\
\hline $\begin{array}{l}\text { e-Government applications accept input data in } \\
\text { simple format }\end{array}$ & 2.88 & 1.51 & 0.96 \\
\hline
\end{tabular}

$\mathrm{ICT}$, information communication technology; SD, standard deviation.

TABLE 7: Confirmatory factor analysis of supporting industries readiness.

\begin{tabular}{lccc}
\hline Conceptual measure & Mean & SD & Loading \\
\hline $\begin{array}{l}\text { Sufficient services involving the internet, cloud and } \\
\text { telecommunication infrastructure from ICT industry }\end{array}$ & 3.06 & 1.60 & 0.96 \\
$\begin{array}{l}\text { Sufficient and reliable services and technical support } \\
\text { from ICT industry }\end{array}$ & 2.96 & 1.54 & 0.96 \\
$\begin{array}{l}\text { Services and transactions } \\
\begin{array}{l}\text { Ability of courier and logistic industry to integrate } \\
\text { e-government services and product delivery }\end{array}\end{array}$ & 2.74 & 1.48 & 0.94 \\
$\begin{array}{l}\text { Ability of financial and commercial institutions to } \\
\text { support secured technology infrastructure for } \\
\text { e-government transactions }\end{array}$ & 2.65 & 1.46 & 0.93 \\
$\begin{array}{l}\text { Ability of qualified legal expertise to draw up related } \\
\text { e-government contracts and agreements }\end{array}$ & 2.62 & 1.43 & 0.92 \\
\hline
\end{tabular}

$\mathrm{ICT}$, information communication technology; SD, standard deviation.

TABLE 8: Confirmatory factor analysis of municipal e-government readiness.

\begin{tabular}{lccc}
\hline Conceptual measure & Mean & SD & Loading \\
\hline $\begin{array}{l}\text { e-Government agenda is on the top list of municipality } \\
\text { government priorities }\end{array}$ & 3.03 & 1.67 & 0.72 \\
$\begin{array}{l}\text { e-Government in the municipality is attracting citizen } \\
\text { audience }\end{array}$ & 3.05 & 1.62 & 0.69 \\
$\begin{array}{l}\text { e-Government readiness status of the municipality is } \\
\text { encouraging }\end{array}$ & 3.03 & 1.63 & 0.69 \\
$\begin{array}{l}\text { e-Government development in the municipality is } \\
\text { improving }\end{array}$ & 2.97 & 1.60 & 0.67 \\
$\begin{array}{l}\text { e-Government activities have started in the municipality } \\
\text { e-Gove }\end{array}$ & 2.99 & 1.69 & 0.63 \\
\hline
\end{tabular}

SD, standard deviation.

were used to generate data for the evaluation of the municipal e-government readiness framework. To overcome this deficiency and strengthen the possibility of generalising the study findings, future research should test the readiness framework using a large data sample from different municipalities across other provinces. Moreover, the data collected heavily depend on the perception of government employees, without considering the views of the other stakeholders such as citizens and business partners. Although government employees are the core people participating in government operations and services, it would be prudent for further research to involve diversified user groups engaging with all the constituents of government at the municipal level. This effort would be definitely helpful for the generalisation of the study results to a wider community. 


\section{Conclusion}

e-Government has become the key term that describes the modernisation of the processes and functions of government using the tools of ICT to improve access to and delivery of government services to benefit society, business partners and employees. Through new applications of technologies, e-government provides people with convenient access to government information and services. It improves the quality of services and creates greater opportunities to participate in democratic institutions and processes. Specific e-government services are increasingly being implemented at the national level, followed by the provincial level before they cascade to the municipal level. Previous studies have argued that local governments are closer to the citizens who have better access to the services provided by the municipalities rather than provincial or national governments (Mawela, Ochara \& Twinomurinzi 2016). Consequently, the focus of this study has been on e-government readiness at the municipal level.

The evaluation of municipal e-government readiness provides policy and decision makers with a detailed scorecard of the current status of their municipalities. This underlines the importance of conducting research to develop a framework for evaluating the readiness status of e-government at the municipal level. This study develops and tests an e-government readiness framework that can be used to evaluate e-government initiatives at the municipal level of government. The readiness framework presents five primary building blocks that represent the basic factors to be evaluated before launching an e-government agenda that can guarantee the right implementation of government projects in the right direction. These factors are useful inputs to the formulation of policies and strategies for effective implementation of e-government. The knowledge acquired from this study can potentially benefit policymakers, decision makers and all interested groups in preparing for an efficacious implementation of e-government projects. The information from this study may also help to recognise that effective implementation of e-government requires the use of technologies to achieve more efficiency in the proper functioning of government and to enhance the delivery of government services to industries and individual citizens.

\section{Acknowledgements}

The authors would like to acknowledge the University's financial support for the first author through the Teaching and Development Grant, courtesy of the Department of Higher Education and Training in South Africa.

\section{Competing interest}

The authors declare that they have no financial or personal relationships which may have inappropriately influenced them in writing this article.

\section{Authors' contributions}

O.O. was the project supervisor, O.O. initiated the project, designed the survey and edited the paper. $\mathrm{S}$ was responsible for the administration of the survey, executed the research, performed the statistical analysis and wrote the initial draft paper.

\section{References}

Ahmed, A.O. \& Hussein, A.O., 2006, 'E-government readiness assessment model', Journal of Computer Science 2(11), 841-845.

Aibinu, A.A. \& Al-Lawati, A.M., 2010, 'Using PLS-SEM technique to model construction organizations' willingness to participate in e-bidding', Automation in Construction 19(6), 714-724.

Alavifar, A., Karimimalayer, M. \& Anuar, M.K., 2012, 'Structural equation modeling vs multiple regression', Engineering Science and Technology: An International Journal 2(2), 326-329.

Alghamdi, I.A., Goodwin, R. \& Rampersad, G., 2011, 'E-government readiness assessment for government organizations in developing countries', Computer and Information Science 4(3), 3-17.

Alghamdi, I.A., Goodwin, R. \& Rampersad, G., 2014, 'Organizational E-government readiness: An investigation in Saudi Arabia', International Journal of Business and Management 9(5), 14-24.

Alghamdi, I.A., Goodwin, R. \& Rampersad, G. 2016, 'Ready, set, govern: Readiness of Saudi Arabian Organizations for e-Government', International Journal of Electronic Government Research (IJEGR) 12(1), 69-98.

Angeleski, M., Mitrevski, P., Rocheska, S. \& Lashkoska, A., 2014, 'Regional pilot study to evaluate $\mathrm{E}$ readiness and local E government services', International Journal of Managing Public Sector Information and Communication Technologies (IJMPICT) 5(2), 1-10.

Azab, N.A., Kamel, S. \& Dafoulas, G., 2009, 'A suggested framework for assessing electronic government readiness in Egypt', Electronic Journal of e-Government 7(1), 11-28.

Baeuo, M.O.M., Rahim, N.Z.B.A. \& Alaraibi, A.A.M., 2017, 'Technology factors influencing e-government readiness', Journal of Theoretical \& Applied Information Technology 95(8), 1637-1645.

Dzhusupova, Z., Shareef, M., Ojo, A. \& Janowski, T., 2010, 'Methodology for e-government readiness assessment-models, instruments, implementation', in Proceedings of the International Conference on Society and Information Proceedings of the International Conferen
Technologies (ICSIT 2010), Orlando, FL, 6-9.

Gupta, A., Shakya, S. \& Marasini, S., 2015, 'E-readiness assessment for ministries of Nepal for implementation of e-government', in International Conference on Data Mining, Electronics and Information Technology (DMEIT'15), Pattaya, Thailand, August 10-11, pp. 155-162.

Hair, J.F., Ringle, C.M. \& Sarstedt, M., 2011, 'PLS-SEM: Indeed a silver bullet', Journal of Marketing Theory \& Practice 19(2), 139-152.

Hair, J.F., Sarstedt, M., Ringle, C.M. \& Mena, J.A., 2012, 'An assessment of the use of partial least squares structural equation modeling in marketing research', Journa of the Academy of Marketing Science 40(3), 414-433.

Joseph, S., 2014, 'Development and validation of a framework for e-government readiness measurement', M Tech thesis, Department of Information Technology, Durban University of Technology.

Khalil, O.E., 2011, 'e-Government readiness: Does national culture matter?' Government Information Quarterly 28(3), 388-399.

Koh, C.E., Prybutok, V.R. \& Zhang, X., 2008, 'Measuring e-government readiness', Information \& Management 45(8), 540-546.

Krauss, K., 2009, 'An assessment of e-readiness in KwaZulu-Natal local municipalities: A perspective on the uMngeni local municipality', in Proceedings of the 13th International Business Information Management Conference, Marrakech, Morocco, 864-874.

Máchová, R. \& Lněnička, M., 2015, 'Reframing e-government development indices with respect to new trends in ICT', Review of Economic Perspectives 15(4), 383-412.

Mawela, T., Ochara, N.M. \& Twinomurinzi, H., 2016, 'E-government implementation: Lessons from South African municipalities', in Proceedings of the Annua Conference of the South African Institute of Computer Scientists and Information Technologists, Johannesburg, South Africa, 23, ACM.

Mawela, T., Ochara, N.M. \& Twinomurinzi, H., 2017, 'E-government implementation: A reflection on South African municipalities', South African Computer Journal 29(1), 147-171.

Potnis, D.D., 2010, 'Measuring e-governance as an innovation in the public sector', Government Information Quarterly 27(1), 41-48.

Rahman, H., 2007, 'E-government readiness: From the design table to the grass roots', paper presented at the 1st International Conference on Theory and Practice of Electronic Governance, Macao, China, 225-232, ACM.

Rehman, M., Esichaikul, V. \& Kamal, M., 2012, 'Factors influencing e-government adoption in Pakistan', Transforming Government: People, Process and Policy 6(3), 258-282.

Sarrayrih, M.A. \& Sriram, B., 2015, 'Major challenges in developing a successful e-government: A review on the Sultanate of Oman', Journal of King Saud University - Computer and Information Sciences 27(2), 230-235. 
Sayin, E. \& Okursoy, A., 2013, 'Assessing e-government service quality model and an application: An example of municipality of Nazilli', International Journal of e-Business and e-Government Studies 5(2), 34-47.

Scholtz, J. \& Consolvo, S., 2004, 'Towards a framework for evaluating ubiquitous computing applications', IEEE Pervasive Computing, 3(2), 82-88.

Shin-Ping Liu, T., 2012, 'Assessing and modeling the readiness of electronic government', International Journal of Electronic Commerce Studies 3(2), 251-270.

Singh, A. \& Chauhan, R., 2012, 'Technology challenges in e-service accessibility', Journal of Engineering and Technology 2(1), 32-40.

Tavakol, M. \& Dennick, R., 2011, 'Making sense of Cronbach's alpha', International Journal of Medical Education 2, 53-55.

Tenenhaus, M., Vinzi, V.E., Chatelin, Y.M. \& Lauro, C., 2005, 'PLS path modeling', Computational Statistics \& Data Analysis 48(1), 159-205.

Twum-Darko, M., 2014, 'Factors influencing readiness for transformationa e-government: A perspective of local governments in South Africa', Journal of e-government: A perspective of local
Public Administration 49(2), 512-523.
UNDESA, 2008, UN e-government survey 2008: From e-government to connected governance, viewed on 24/01/2018 from http://unpan1.un.org/intradoc/groups/ public/documents/un/unpan028607.pdf

Waheduzzaman, W. \& Miah, S.J., 2015, 'Readiness assessment of e-government: A developing country perspective', Transforming Government: People, Process and Policy 9(4), 498-516.

Yuan, L., Xi, C. \& Xiaoyi, W., 2012, 'Evaluating the readiness of government portal websites in China to adopt contemporary public administration principles', Government Information Quarterly 29(3), 403-412.

Yunis, M.M. \& Sun, J., 2009, 'Determinants of e-government readiness: An application of canonical correlation and SEM analysis techniques', in 40th Southwest Region Decision Sciences Institute Conference, Oklahoma, 569-578.

Zheng, L. \& Jiang, Y., 2011, 'Assessing e-government readiness of local governments in China: Developing a bottom-up approach', in Proceedings of the 5th International Conference on Theory and Practice of Electronic Governance, Tallinn, Estonia, 91-96. ACM. 